Abstracta Iranica Abstracta Iranica

Revue bibliographique pour le domaine irano-aryen

Volume 23 | 2002

Comptes rendus des publications de $\mathbf{2 0 0 0}$

\title{
« Reflections on the Presence of the Attic Pottery at the Eastern End of the Mediterranean during the Persian Period ». Transeuphratène, 19, pp. 75-82.
}

\section{Astrid Nunn}

\section{OpenEdition}

Journals

Édition électronique

URL : http://journals.openedition.org/abstractairanica/35209

DOI : 10.4000/abstractairanica.35209

ISSN : 1961-960X

Éditeur :

CNRS (UMR 7528 Mondes iraniens et indiens), Éditions de l'IFRI

Édition imprimée

Date de publication : 15 mai 2002

ISSN : 0240-8910

Référence électronique

Astrid Nunn, « « Reflections on the Presence of the Attic Pottery at the Eastern End of the Mediterranean during the Persian Period ». Transeuphratène, 19, pp. 75-82. », Abstracta Iranica [En

ligne], Volume 23 | 2002, document 43, mis en ligne le 08 février 2010, consulté le 25 septembre 2020. URL : http://journals.openedition.org/abstractairanica/35209; DOI : https://doi.org/10.4000/ abstractairanica.35209

Ce document a été généré automatiquement le 25 septembre 2020.

Tous droits réservés 


\section{« Reflections on the Presence of the} Attic Pottery at the Eastern End of the Mediterranean during the Persian Period ». Transeuphratène , 19, pp. 75-82.

\section{Astrid Nunn}

Bref survol de la céramique grecque au Proche Orient et des questions qu'elle soulève. Une fois de plus la céramique grecque est traitée abstraitement, indépendamment de la céramique locale ou d'autres objets étrangers.

\section{INDEX}

Thèmes : 3.0. Généralités

\section{AUTEURS}

ASTRID NUNN

Université de Munich (Allemagne) 